Pak. j. sci. ind. res. Ser. A: phys. sci. 2019 62A(3) 181-189

\title{
Multivariate Analysis of Heavy Metals, Physicochemical and Microbial Characteristics to Determine the Water Quality of Lower Indus Basin, Pakistan
}

\author{
Waqar Ahmad ${ }^{\text {a*}}$, Arif Zubair ${ }^{\mathrm{a}}$, Zafar Iqbal Shams ${ }^{\mathrm{b}}$, Haq Nawaz Abbasi, \\ Muhammad Usama Zafar ${ }^{a}$ and Muhammad Afzal Farooq ${ }^{a}$ \\ ${ }^{a}$ Department of Environmental Science, Federal Urdu University of Arts, Science and Technology \\ Gulshan-e-Iqbal Karachi, Pakistan \\ ${ }^{b}$ Institute of Environmental Studies, University of Karachi, Karachi-75270, Pakistan
}

(received March 29, 2019; revised May 24, 2019; accepted June 17, 2019)

\begin{abstract}
This study was conducted to assess the water quality of the lower Indus Basin, Pakistan. Eightytwo water samples were collected from forty-one locations of lower Indus Basin (Kashmore to Keti-Bander) during pre and post monsoon seasons. The variation pattern in the water quality has been observed in both seasons. The samples were analysed for physical quality (temperature, $\mathrm{pH}$, turbidity, dissolved oxygen, total dissolved solids, salinity and conductivity), chemical quality (chloride, total alkalinity, total hardness, sulphate, potassium, sodium, iron, zinc, lead, mercury, copper, cadmium and nitrate) and biological quality (coliform bacteria). The study reveals that the concentrations of lead, mercury, and cadmium in water samples during both seasons were slightly higher than the permissible limits, whereas, all other parameters were within WHO guidelines. The higher concentration of heavy metals must be rectified by the concerned authorities in order to protect human health.
\end{abstract}

Keywords: water quality, lower Indus basin, multivariate, monsoon, heavy metals

\section{Introduction}

Water is one of the plentiful natural resources present on the surface of the earth and one of the most essential needs of humans, plants and animals (Agbalagba et al., 2011; Oyinloye and Jegede, 2004). Approximately 70 percent of the earth surface is covered with water (Tiuri and Hallikainen, 1981). From total water 97.3 percent water is saline and non-potable, only 2.7 percent is freshwater. Whereas from freshwater 77.6 percent water is locked in the form of glaciers and ice caps, remaining 22.4 percent is in the form of groundwater, soil moisture, swamps, lakes, streams, and rivers (Dhonde and Kulkarni, 2012). Water is essential to sustain life and is a precious commodity. Like air, "safe, potable water and sanitation are integral for the realization of all human rights" (UN, 2010). Water is a universal solvent as it dissolves organic and inorganic compounds, salts and exchange gases that take part in metabolic reactions. Water stabilizes plasma membrane, maintain thermoregulation, macromolecular framework, transport nutrients, maintain body volume/weight and hemostasis (Shar, 2010). More than 70 percent of the human body and just 80 percent of a microorganism weight comprises

*Author for correspondence; E-mail: waqarevs@gmail.com of water. Water act as a natural air conditioner inside the human body and helps in regulating human body temperature (Houdas and Ring, 1982).

Polluted drinking water causes adverse effects on human health. Access and use of safe drinking water is the basic human necessity as well as the right of the people. Drinking water is considered safe for human consumption which meets the criteria of the National Drinking Water Quality and WHO standards. Access implies that at least 20 liters water should be available per person daily from an improved source within one kilometer. The water quality parameters are briefly dealt with in the sequel. A wide variety of infectious diseases is caused by water, which is contaminated with animal and human excreta (WHO, 2004). LeChevallier et al. (1991) stated that the presence of coliform organisms in water is an indicator of biological contamination. Therefore, the analysis of entire pathogens is necessary for routine analysis of the water quality. Water is a valuable resource for humans, which must be conserved. Microbial contaminations and physicochemical characteristics of river water should be monitored for the supply of safe drinking water (Lee et al., 2002). When it rains, the water flows as run-off and passes 
through ground surface and enters in the ponds, lakes, and rivers. On its way to the ultimate users, the water gets contaminated by acids, salts, heavy metals, minerals, radioactive substances and pathogenic bacteria (Gillespie, 1994).

Pakistan is currently experiencing the problem of drinking water quality in terms of microbial, physical and chemical parameters. The contamination of drinking water may be caused by several possible sources. It is generally thought that the drinking water is not suitable for human consumption, because of its foul smell, bad colour, and turbidity. The drinking water of both the rural and urban areas of the country demonstrated bacteriological contamination. It is considered as one of the most serious problems (Inam and Alam, 2014). The predominant sources of contamination include leakage of pipes, polluted shallow water tables, sewerage lines and other anthropogenic activities including, runoff from agricultural lands that carry fertilizers, pesticides, insecticides, and other chemicals. The discharge of industrial effluent in the river may deteriorate the water quality because the effluent contains dyes, heavy metals and many organic and inorganic chemicals (Tahir et al., 2010).

Indus River is most important and largest source of water in Pakistan which covers an area of 1,165,000 $\mathrm{km}^{2}$ and has an economic and social significance (Swain, 2004). The Indus River is nourished by snows and glaciers of the Himalayas, Hindukush, Karakorum, Northern areas of Pakistan and Jammu and Kashmir. Indus River comprises of two basins i.e. upper Indus Basin and the lower Indus Basin (Zafar, 2013).

A study on the quality of Indus River water by Ata et al. (2013) revealed that concentration level of iron, manganese, and lead was higher than maximum contamination limits and caused rusty spots on teeth of the residents. Another study by Lashari et al. (2012) on heavy metals in Keenjhar lake showed that concentration of nickel and cadmium were higher than WHO limits. Various previous studies on freshwater around Rohri and Sukkar region showed the presence of fecal coliform in most of the samples (Shar, 2010 Shar et al., 2010; 2009). The purpose of the present study is to investigate the quality parameters (physical, chemical, heavy metals, and fecal contamination) of river water, which were collected from forty-one locations of lower Indus Basin of Sindh province.

\section{Materials and Methods}

Sampling and on-site evaluation. The area from Kashmore to Keti-Bander in lower Indus Basin was selected for this study. Forty-one representing sampling locations close to basin were selected (Fig. 1) and eighty-two samples were collected during pre and post monsoon seasons for comparison study. The samples were taken in one-liter polyethylene bottles for chemical analysis and $100 \mathrm{~mL}$ for bacteriological analysis without deterioration or getting contamination with any substance. The bottles were rinsed with distilled water and sampled water before taking samples. The samples of chemical analysis immediately acidified by adding concentrated nitric acid for trace metal preservation. The physical analysis $(\mathrm{pH}$, temperature, salinity, electrical conductivity, total dissolved solids, dissolved oxygen and turbidity) were performed at the site with the help of Instrument $156 \mathrm{HACH}$ potable multiparameter, USA and Turbidimeter. The sampling, preservation, and transportation were carried out according to standard procedures (APHA, 2005).

Laboratory analyses. Chemical and biological analyses were carried out in the laboratory to find out chloride, total alkalinity $\left(\mathrm{CO}_{3}+\mathrm{HCO}_{3}\right)$, total hardness $(\mathrm{Ca}+\mathrm{Mg})$, sodium, potassium, sulphate, nitrate, chemical oxygen demand (COD), iron, zinc, copper, cadmium, lead, mercury and coliform. Titrimetric methods were used for the analysis of total hardness, total alkalinity, and chloride; spectrophotometer was used for iron, zinc sulphate, nitrate, and chemical oxygen demand (COD);

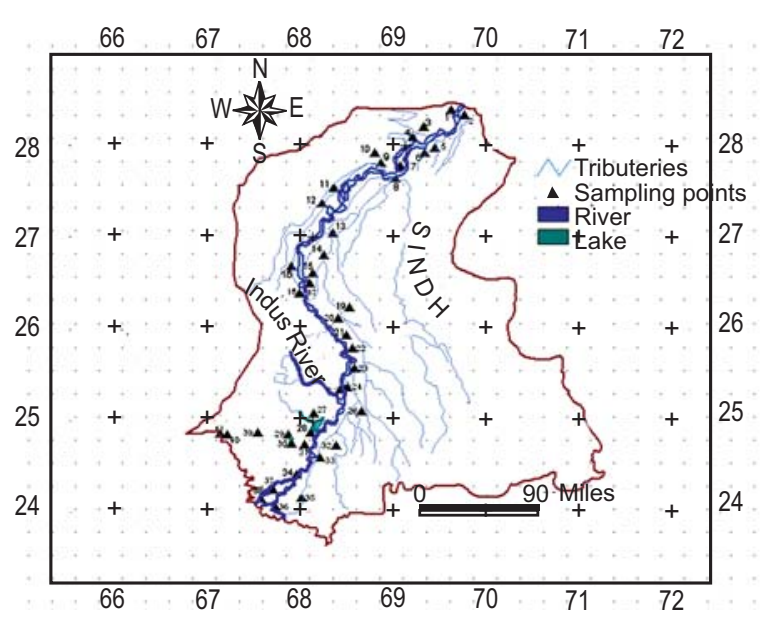

Fig. 1. Map showing sampling points in the study area. 
flame-photometer for sodium and potassium, whereas atomic absorption spectrophotometer was used to analyze copper, cadmium, lead and mercury. Most Probable Number (MPN) technique was used for the detection of coliform according to the standard procedure (Anwar et al., 2010).

Statistical analysis. Initial data was recorded in MS Exel and then Minitab version (11.12) was used for statistical analyses. Correlation matrix for both the preand post-monsoon periods was created among all parameters to investigate the effects of one parameter to another parameter. Multivariate techniques, principal component analysis (PCA) and cluster analysis (CA) were applied to the data to achieve comprehensive results.

\section{Results and Disussion}

Pearson correlation matrix of pre-monsoon season. The pearson correlation matrix (Table 1) was computed for the pre-monsoon season for twenty-two parameters of 41 water samples of lower Indus Basin. The significance level for each correlation coefficient was determined. The temperature was significantly correlated with ten parameters. The temperature was negatively correlated with turbidity, total alkalinity, zinc and lead while its positive correlation was found with conductivity, chloride, total hardness, sulphate, sodium, and mercury. Water $\mathrm{pH}$ was significantly correlated with ten parameters. Of which, turbidity, lead, and COD were negatively correlated with water $\mathrm{pH}$ while TDS, conductivity, salinity, chloride, total hardness, sulphate, and sodium demonstrated a positive correlation with water $\mathrm{pH}$. Turbidity showed significant correlation with nine parameters, of which it is negatively correlated with eight parameters and positively correlated with only one parameter i.e., lead. Dissolved oxygen did not show any correlation with any of the studied parameters. Total dissolved solid was negatively correlated with only one parameter, i.e., lead and strongly positively correlated with seven parameters. Conductivity was negatively correlated with lead while positively correlated with six parameters. Salinity and chloride demonstrated a negative correlation with lead and positive correlation was found with five and four parameters, respectively. Total alkalinity did not show any significant correlation except negative correlation with chemical oxygen demand and total hardness was

Table 1. Correlation matrix of mean values of 22 parameters of 41 samples of Indus River (pre-monsoon season)

\begin{tabular}{|c|c|c|c|c|c|c|c|c|c|c|c|c|c|c|c|c|c|c|c|c|}
\hline & Tem. & $\mathrm{pH}$ & Tur. & DO & TDS & Con. & Sal. & $\mathrm{Cl}^{-}$ & TA & $\mathrm{TH}$ & $\mathrm{SO}_{4}$ & $\mathrm{~K}$ & $\mathrm{Na}$ & $\mathrm{Cd}$ & $\mathrm{Fe}$ & $\mathrm{Zn}$ & $\mathrm{Pb}$ & $\mathrm{Hg}$ & $\mathrm{Cu}$ & $\mathrm{NO}_{3} \mathrm{COD}$ \\
\hline $\mathrm{pH}$ & 0.17 & & & & & & & & & & & & & & & & & & & \\
\hline Tur. & -0.37 & -0.43 & & & & & & & & & & & & & & & & & & \\
\hline DO & -0.19 & 0.25 & 0.14 & & & & & & & & & & & & & & & & & \\
\hline TDS & 0.22 & 0.46 & -0.82 & -0.06 & & & & & & & & & & & & & & & & \\
\hline Con. & 0.35 & 0.43 & -0.90 & -0.12 & 0.90 & & & & & & & & & & & & & & & \\
\hline Sal. & 0.21 & 0.51 & -0.83 & -0.02 & 0.98 & 0.90 & & & & & & & & & & & & & & \\
\hline Cl- & 0.34 & 0.42 & -0.91 & -0.07 & 0.92 & 0.98 & $0.917^{*}$ & & & & & & & & & & & & & \\
\hline TA & -0.33 & 0.01 & 0.02 & -0.30 & -0.03 & -0.05 & -0.04 & -0.02 & & & & & & & & & & & & \\
\hline $\mathrm{TH}$ & 0.42 & 0.38 & -0.71 & -0.01 & 0.73 & 0.84 & 0.73 & 0.83 & -0.19 & & & & & & & & & & & \\
\hline $\mathrm{SO}_{4}$ & 0.38 & 0.43 & -0.86 & -0.11 & 0.84 & 0.89 & 0.82 & 0.90 & 0.09 & 0.75 & & & & & & & & & & \\
\hline $\mathrm{K}$ & 0.26 & 0.25 & -0.74 & 0.00 & 0.78 & 0.87 & 0.76 & 0.83 & -0.07 & 0.69 & 0.72 & & & & & & & & & \\
\hline $\mathrm{Na}$ & 0.65 & 0.50 & -0.83 & -0.24 & 0.68 & 0.78 & 0.69 & 0.79 & 0.08 & 0.67 & 0.78 & 0.57 & & & & & & & & \\
\hline $\mathrm{Cd}$ & -0.16 & 0.08 & 0.20 & 0.04 & -0.10 & -0.12 & -0.10 & -0.12 & 0.18 & -0.09 & -0.16 & -0.10 & -0.11 & & & & & & & \\
\hline $\mathrm{Fe}$ & 0.04 & -0.02 & 0.18 & 0.11 & -0.11 & -0.12 & -0.08 & -0.16 & -0.27 & 0.13 & -0.12 & -0.14 & -0.20 & 0.10 & & & & & & \\
\hline $\mathrm{Zn}$ & -0.34 & -0.07 & 0.28 & 0.07 & -0.19 & -0.28 & -0.15 & -0.28 & 0.14 & -0.38 & -0.30 & -0.24 & -0.23 & -0.02 & -0.27 & & & & & \\
\hline $\mathrm{Pb}$ & -0.64 & -0.52 & 0.71 & 0.02 & -0.59 & -0.73 & -0.61 & -0.73 & 0.03 & -0.67 & -0.71 & -0.53 & -0.91 & 0.03 & 0.06 & 0.24 & & & & \\
\hline $\mathrm{Hg}$ & 0.44 & 0.03 & -0.21 & -0.18 & 0.11 & 0.09 & 0.11 & 0.11 & -0.29 & -0.02 & 0.15 & -0.08 & 0.23 & -0.22 & -0.08 & -0.13 & -0.12 & & & \\
\hline $\mathrm{Cu}$ & -0.18 & -0.05 & 0.13 & -0.11 & -0.14 & -0.14 & -0.13 & -0.15 & 0.06 & -0.15 & -0.20 & -0.04 & -0.24 & -0.04 & -0.12 & -0.05 & 0.29 & -0.04 & & \\
\hline $\mathrm{NO}_{3}$ & 0.13 & 0.15 & 0.08 & 0.04 & 0.13 & -0.03 & 0.18 & 0.04 & 0.28 & -0.01 & 0.07 & -0.14 & 0.17 & 0.27 & 0.11 & -0.01 & -0.15 & -0.01 & -0.06 & \\
\hline COD & -0.09 & -0.49 & 0.24 & -0.02 & -0.27 & -0.28 & -0.28 & -0.28 & -0.47 & -0.18 & -0.33 & -0.17 & -0.46 & -0.13 & 0.19 & -0.09 & 0.49 & 0.20 & 0.35 & -0.20 \\
\hline $\begin{array}{l}\text { Coli- } \\
\text { form }\end{array}$ & -0.02 & -0.09 & 0.09 & -0.16 & -0.21 & -0.14 & -0.17 & -0.14 & 0.10 & -0.02 & -0.18 & -0.19 & 0.07 & 0.27 & -0.03 & 0.19 & -0.07 & -0.05 & 0.01 & $0.07-0.05$ \\
\hline
\end{tabular}

Here, Temp. $=$ Temperature; Tur. $=$ Turbidity; DO = Dissolve Oxygen; TDS = Total Dissolve Solids; Con. = Conductivity; Sal. = Salinity; $\mathrm{Cl}=$ Chloride; $\mathrm{TH}=$ Total Hardness; $\mathrm{SO} 4=$ Sulfate; $\mathrm{K}=$ Patassium; $\mathrm{Na}=$ Sodium; $\mathrm{Cd}=\mathrm{Cadmium} ; \mathrm{Fe}=\mathrm{Iron} ; \mathrm{Zn}=\mathrm{Zinc}$; $\mathrm{Pb}=$ Lead; $\mathrm{Hg}=$ Murcery; $\mathrm{Cu}=$ Copper; $\mathrm{NO} 3=$ Nitrate $\mathrm{COD}=$ Chemical Oxygen Demand. 
Table 2. Correlation matrix of mean values of 22 parameters of 41 samples of Indus River (post-monsoon season)

\begin{tabular}{|c|c|c|c|c|c|c|c|c|c|c|c|c|c|c|c|c|c|c|c|c|}
\hline & Tem. & $\mathrm{pH}$ & Tur. & $\mathrm{DO}$ & TDS & Con. & Sal. & Cl- & TA & $\mathrm{TH}$ & $\mathrm{SO} 4$ & $\mathrm{~K}$ & $\mathrm{Na}$ & $\mathrm{Cd}$ & $\mathrm{Fe}$ & $\mathrm{Zn}$ & $\mathrm{Pb}$ & $\mathrm{Hg}$ & $\mathrm{Cu}$ & $\mathrm{NO} 3 \mathrm{COD}$ \\
\hline $\mathrm{pH}$ & 0.06 & & & & & & & & & & & & & & & & & & & \\
\hline Tur. & -0.34 & -0.11 & & & & & & & & & & & & & & & & & & \\
\hline DO & 0.21 & 0.07 & 0.21 & & & & & & & & & & & & & & & & & \\
\hline TDS & 0.03 & 0.06 & -0.42 & -0.39 & & & & & & & & & & & & & & & & \\
\hline Con. & 0.08 & 0.06 & -0.44 & -0.39 & 1.00 & & & & & & & & & & & & & & & \\
\hline Sal. & 0.10 & 0.01 & -0.43 & -0.42 & 0.97 & 0.97 & & & & & & & & & & & & & & \\
\hline $\mathrm{Cl}-$ & 0.49 & 0.10 & -0.43 & -0.20 & 0.71 & 0.74 & 0.73 & & & & & & & & & & & & & \\
\hline $\mathrm{TA}$ & 0.18 & -0.34 & -0.19 & -0.31 & 0.34 & 0.35 & 0.37 & 0.50 & & & & & & & & & & & & \\
\hline TH & -0.14 & 0.12 & -0.31 & -0.11 & 0.61 & 0.59 & 0.58 & 0.22 & 0.00 & & & & & & & & & & & \\
\hline $\mathrm{SO} 4$ & 0.15 & -0.04 & -0.35 & -0.32 & 0.91 & 0.92 & 0.89 & 0.81 & 0.44 & 0.49 & & & & & & & & & & \\
\hline K & 0.03 & 0.01 & -0.37 & -0.42 & 0.86 & 0.86 & 0.82 & 0.66 & 0.29 & 0.49 & 0.86 & & & & & & & & & \\
\hline $\mathrm{Na}$ & 0.87 & 0.08 & -0.21 & 0.17 & -0.02 & 0.03 & 0.04 & 0.54 & 0.29 & -0.42 & 0.15 & 0.03 & & & & & & & & \\
\hline $\mathrm{Cd}$ & -0.29 & 0.08 & -0.03 & -0.18 & 0.20 & 0.18 & 0.17 & -0.13 & -0.13 & 0.31 & 0.02 & 0.20 & -0.35 & & & & & & & \\
\hline $\mathrm{Fe}$ & -0.02 & 0.04 & 0.21 & 0.07 & -0.05 & -0.05 & -0.04 & -0.05 & 0.05 & -0.06 & 0.01 & -0.04 & -0.06 & -0.03 & & & & & & \\
\hline $\mathrm{Zn}$ & 0.19 & 0.18 & -0.23 & -0.10 & 0.04 & 0.05 & 0.05 & 0.05 & -0.08 & -0.03 & -0.01 & 0.11 & 0.12 & 0.08 & -0.11 & & & & & \\
\hline $\mathrm{Pb}$ & 0.63 & -0.05 & -0.14 & 0.19 & 0.03 & 0.06 & 0.08 & 0.42 & 0.22 & -0.26 & 0.17 & -0.03 & 0.63 & -0.34 & -0.05 & 0.00 & & & & \\
\hline $\mathrm{Hg}$ & 0.30 & 0.30 & 0.09 & 0.45 & -0.26 & -0.24 & -0.28 & -0.03 & -0.15 & -0.28 & -0.20 & -0.19 & 0.31 & -0.08 & -0.07 & 0.28 & 0.08 & & & \\
\hline $\mathrm{Cu}$ & -0.42 & 0.07 & 0.19 & -0.09 & -0.22 & -0.24 & -0.31 & -0.39 & -0.25 & 0.05 & -0.27 & -0.17 & -0.44 & 0.23 & -0.27 & -0.06 & -0.26 & 0.00 & & \\
\hline NO3 & 0.00 & 0.08 & 0.01 & 0.05 & -0.05 & -0.05 & 0.00 & 0.05 & -0.06 & 0.09 & -0.11 & -0.06 & -0.03 & -0.12 & 0.34 & -0.14 & 0.13 & -0.02 & -0.12 & \\
\hline COD & -0.18 & 0.24 & -0.10 & -0.11 & 0.16 & 0.16 & 0.16 & -0.06 & -0.08 & 0.42 & 0.04 & 0.24 & -0.34 & 0.57 & 0.10 & 0.37 & -0.49 & 0.16 & 0.13 & -0.05 \\
\hline $\begin{array}{l}\text { Coli } \\
\text { form }\end{array}$ & -0.19 & -0.17 & -0.13 & -0.26 & 0.29 & 0.28 & 0.25 & -0.03 & 0.01 & 0.49 & 0.17 & 0.19 & -0.36 & 0.35 & -0.16 & 0.04 & -0.29 & -0.16 & 0.18 & -0.080 .36 \\
\hline
\end{tabular}

Here, Temp. $=$ Temperature; Tur. $=$ Turbidity; DO = Dissolve Oxygen; TDS = Total Dissolve Solids; Con. = Conductivity; Sal. = Salinity; $\mathrm{Cl}=$ Chloride TH = Total Hardness; $\mathrm{SO} 4=$ Sulfate $\mathrm{K}=$ Patassium; $\mathrm{Na}=$ Sodium; $\mathrm{Cd}=\mathrm{Cadmium} ; \mathrm{Fe}=\mathrm{Iron}$; $\mathrm{Zn}=\mathrm{Zinc} ; \mathrm{Pb}=$ Lead; $\mathrm{Hg}=$ Murcery $\mathrm{Cu}=$ Copper; $\mathrm{NO} 3=$ Nitrate COD = Chemical Oxygen Demand

positively correlated with sulphate, potassium, and sodium while negatively correlated with zinc and lead. Sulphate was found positively correlated with potassium and sodium and negatively correlated with lead and COD. Potassium was negatively correlated with lead and positively correlated with sodium. Sodium was found to be negatively correlated with lead and COD. Heavy metals did not show correlation with any of the parameters except lead and copper.

Pearson correlation matrix of post-monsoon season. Correlation of all parameters during the post-monsoon season are shown in Table 2. The temperature was negatively correlated with turbidity and copper and positively correlated with chloride, sodium, and lead. Water $\mathrm{pH}$ showed a negative correlation with total alkalinity. Turbidity was negatively correlated with seven parameters.

Dissolved oxygen was positively correlated with mercury while negatively correlated with six parameters. Total dissolved solids showed a strong positive correlation with seven parameters. The same is the case with conductivity and salinity which showed a strong positive correlation with five parameters. Chlorides expressed positive correlation with total alkalinity, sulphate, potassium, sodium and lead while a negative correlation with copper. Total alkalinity showed significant correlation with sulphate. Total hardness revealed a positive correlation with five parameters and negative correlation only with sodium. Sulphate is strongly positively correlated with potassium. Sodium is strongly positively correlated with lead and negatively correlated with four parameters. Cadmium disclosed positive correlation with COD and coliform while it showed a negative correlation with lead.

Characteristics of the groups for pre-monsoon season. The characteristics of the four groups derived from the agglomerative cluster analysis are discussed in the sequel (Fig. 2). The temperature was slightly higher in groups III and IV. The water $\mathrm{pH}$ was found slightly more alkaline for groups III and IV. Turbidity and dissolved oxygen (DO) of water were on the higher side for groups I and II. Four parameters TDS, conductivity, salinity, and chloride of water samples showed higher values for groups III and IV. Total alkalinity was found to be higher for groups II and III, whereas hardness was greater for groups III and IV. 


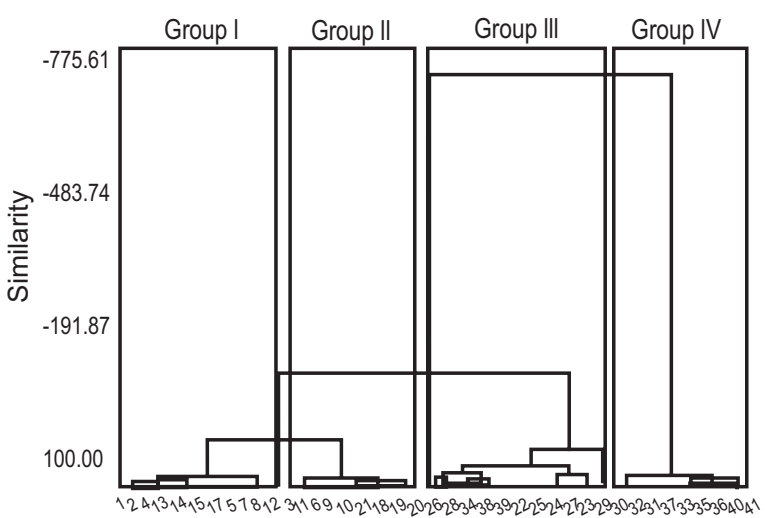

Fig. 2. Dendrogram of pre-monsoon season, derived from agglomerative cluster analysis from the study area.

Sulphate, potassium, and sodium gave higher values for groups III and IV. Among the heavy metals tested, iron and lead were found to have greater concentrations in groups I and II, while cadmium showed greater value for groups I and III. Zinc was found to be very low in group III compared to the other three groups. Mercury showed greater concentration in groups III and IV, while copper demonstrated higher in groups II and III. Nitrate concentration was higher in groups I and III. COD was higher in groups I and II. Coliform bacteria were slightly higher in groups I and III.

Characteristics of the groups for post-monsoon season. The water quality characteristics of the three groups which were derived from agglomerative clustering (Fig. 3) are as follows: Temperature was slightly higher for group III. The water $\mathrm{pH}$ was almost

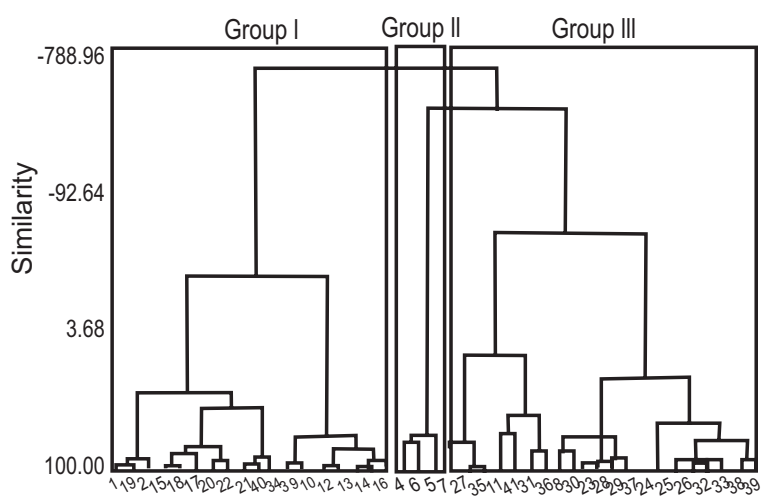

Fig. 3. Dendrogram of post-monsoon season, derived from agglomerative cluster analysis from the study area.

similar for all three groups. Turbidity and DO were high for groups II and III. TDS, conductivity, salinity, total alkalinity, total hardness, and chloride concentration were high for groups II and III. In addition, sulphate and potassium contents were higher for groups II and III. However, sodium content was significantly higher for group III as compared to groups I and II $(\mathrm{P}<0.01)$. Among the heavy metals, cadmium concentration remained equal for all three groups. The concentration of iron was slightly but not significantly higher for group I. On the other hand, zinc, lead $(\mathrm{P}<0.05)$ and mercury concentrations were higher for group III as compared to groups I and II. Copper concentration was low in group III while nitrate was low in group II. COD was high for group II. Likewise, coliform bacteria were found higher for group II. Table 3 shows that there is

Table 3. Water characteristics of pre- and post-monsoon periods and their differences using t-test probability level of significance is given against each variable

\begin{tabular}{llllll}
\hline \hline Variables & t-value & Significance P & Variables & t-value & Significance P \\
\hline Temperature & 29.89 & $<0.001$ & Potassium & 3.03 & $<0.01$ \\
pH & 8.99 & $<0.001$ & Sodium & 0.14 & n.s. \\
Turbidity & 10.22 & $<0.001$ & Cadmium & 1.11 & n.s. \\
DO & 9.88 & $<0.001$ & Iron & 3.45 & $<0.01$ \\
TDS & 0.54 & n.s. & Zinc & 3.47 & $<0.01$ \\
Conductivity & 2.46 & $<0.05$ & Lead & 8.17 & $<0.001$ \\
Salinity & 0.77 & n.s. & Mercury & 6.6 & $<0.001$ \\
Chloride & 16.08 & $<0.001$ & Copper & 2.36 & $<0.05$ \\
Total alkalinity & 20.1 & $<0.001$ & Nitrate & 3.56 & $<0.01$ \\
Total hardness & 1.28 & n.s & COD & 0.23 & n.s. \\
Sulphate & 3.08 & $<0.01$ & Coliform & 0.74 & n.s. \\
\hline \hline
\end{tabular}


Table 4. Comparison of current study with previous studies.

\begin{tabular}{llllll}
\hline \hline Variables & Current study & Rahman et al., 2014 & Farooq et al., 2013 & Lashari et al., 2012 & Korai et al., 2008 \\
\hline Temp. & 31.0857 & - & 23.7 & - & 27.14 \\
pH & 7.67857 & 7.7 & 7.2 & - & 8.23 \\
Turbidity & 186.425 & - & 2.317 & - & - \\
DO & 7.28429 & - & 6.235 & - & 8.01 \\
TDS & 338.821 & 210 & 273.1 & - & 273.75 \\
Conductivity & 685.429 & 0.32 & 637.2 & - & 236.61 \\
Salinity & 0.3 & - & 0.2214 & - & 0.17 \\
Chloride & 98.5714 & 37 & 84.8 & - & 144.23 \\
T alkalinity & 351.429 & 76 & 90.43 & - & 216.22 \\
T hardness & 274.286 & - & 173.1 & - & 226.8 \\
Sulphate & 95.8571 & 28.2 & 94.93 & - & - \\
Potassium & 7.64286 & 2.1 & 18.64 & - & - \\
Sodium & 133.881 & 22.3 & 66.46 & - & - \\
Cadmium & 0.0150143 & - & 0.01003 & 2.65 & - \\
Iron & 0.177214 & - & 0.2807 & 23.8 & - \\
Zinc & 0.0574286 & - & 0.2429 & 52.85 & - \\
Lead & 0.398143 & - & 0.00264 & - & - \\
Mercury & 0.272357 & - & 0.00004 & - & - \\
Copper & 0.125714 & - & 0.05999 & - & - \\
Nitrate & 3.06429 & - & 17.579 & - & - \\
COD & 21.9286 & - & 112.9 & - & \\
Coliform & 6.71429 & - & 3.571 & & \\
\hline \hline
\end{tabular}

a highly significant difference in temperature, $\mathrm{pH}$, turbidity and DO between pre- and post-monsoon water samples $(p<0.001)$. However, TDS and salinity did not differ significantly between the two sampling data. Conductivity was found to be significantly different between pre- and post-monsoon periods $(\mathrm{p}<0.05)$. Sulphate, nitrate, and potassium showed a significant difference between the two sampling seasons $(\mathrm{p}<0.01)$. Sodium concentration did not differ significantly. Chloride and total alkalinity were found to be significantly different at $(\mathrm{p}<0.001)$. Among the heavy metals zinc, iron, mercury, lead, and copper exhibited significant differences between pre- and post-monsoon samples $(\mathrm{p}<0.01, \mathrm{p}<0.01, \mathrm{p}<0.001, \mathrm{p}<0.001$ and $\mathrm{p}<0.05$, respectively). COD did not differ significantly between the two sampling periods. Coliform bacteria did not show a significant difference between pre- and postmonsoon samples.

A number of researchers have assessed water quality of different lakes, rivers and many other water bodies throughout the globe. This study focused on the water quality and characteristics of the Indus River from Kashmore to KT-Bander (near Karachi) in the province of Sindh, Pakistan. Some previous studies have been conducted on lakes and rivers of the country (Table 4).
Limnological study of Keenjhar Lake was carried out by Lashari (Lashari et al., 2009) that dealt with the physicochemical parameters of water including $\mathrm{pH}$, temperature, TDS, conductivity, turbidity, alkalinity, DO, calcium, chloride, and magnesium. The results of the study revealed that all the water quality characteristics of Keenjhar Lake are in accordance with the permissible limits. Physicochemical analysis of drinking water from Khairpur city was conducted to identify the quality of drinking water, which is supplied to the city (Daud et al., 2017). The concentration of $\mathrm{pH}$, total dissolved solids, electrical conductivity, alkalinity, hardness, sulphate, and chloride were measured. Their results showed that concentrations of cations and anions were within safe limits, which were laid down by WHO. The results of physicochemical parameters of the present study are found to be similar with the results, which were reported by Lashari et al. (2009) that the physicochemical parameters of all water samples are within the WHO permissible limits.

Many studies, which were reported earlier, demonstrated that the fecal contamination in drinking water was widespread in both the urban and rural areas of Pakistan. The drinking water from many regions in the country are not suitable for human consumption. For instance, 
the fecal contamination was found higher in a residential area of Lahore City (Anwar et al., 2010) Tarnab, Risalpur, and Pubi (Ihsanullah et al., 1991). Khan et al. (1999) studied thirty-eight water samples from River Kabul and its tributaries for fecal coliform. They reported that Colony Sarhad Textile Mills, Khazana Sugar Mills, Amarjee Paper and Paper Board Mills and many tannery industries are the main sources of organic pollutants and fecal contamination.

Shar et al. (2010) studied the bacteriological contamination in drinking water from surface and underground water samples in Rohri city. They found that water was contaminated with coliforms, which includes Escherichia coli along with other heterotrophic bacteria in both its pre-storage and post-storage. Fecal contamination was also found in the distribution lines, main reservoirs and the tap water of Sukkur City (Shar et al., 2009). The animal excreta, which are deposited its neighborhood of the city, are one of the main causes of microbial contamination. The excreta eventually go into the river and increase the magnitude of $E$. coli and coliform in the potable water of the city (Shar et al., 2010).

According to WHO standards, the permissible limit of coliform bacteria is less than 3 per $100 \mathrm{~mL}$, while water with greater than 10 coliforms per $100 \mathrm{~mL}$ is designated as unsatisfactory (WHO, 2004). Lester and Sterritt (1988) developed categories of water quality, stated that the water with zero total coliform count per 100 $\mathrm{mL}$ is considered as excellent, the water with 1-3 coliforms per $100 \mathrm{~mL}$ is regarded as satisfactory while the water with 1-9 coliforms per $100 \mathrm{~mL}$ of water is termed as intermediate. Water quality is regarded as unsatisfactory when it contains more than 10 coliform bacterial cells per $100 \mathrm{~mL}$.

The permissible limits for physical properties such as $\mathrm{pH}$, temperature, turbidity, TDS, dissolved oxygen, conductivity, and salinity have not been set by the World Health Organization (WHO). The concentration of chloride was found within permissible limits in both the pre- and post-monsoon samples, i.e., below 250 $\mathrm{mg} / \mathrm{L}$. No guidelines were found for total alkalinity and total hardness of water by WHO. Sulphate, potassium, and sodium were also under permissible limits of WHO. The most important consideration is that heavy metal concentrations have exceeded the permissible limits as suggested by WHO except zinc and iron in both the pre-monsoon and post-monsoon seasons. Among all parameters, $\mathrm{Pb}$ concentration was found to be higher compared to other heavy metals of both the seasons. Figure. 3 also shows that the mean values of postmonsoon season are less than the mean values of premonsoon season. This could be the result of excessive floods or inflow of water into the river from the point and non-point sources after heavy monsoon rains, which diluted the concentration of heavy metal. These results appear to be in agreement with the findings of Zubair et al. (2010), who examined the impact of stormwater on the quality of groundwater. The samples were collected from 33 monitoring wells during pre- and post-monsoon seasons. It was found that the recharge by stormwater infiltration decreased the concentrations of heavy metals such as lead, iron, and zinc in groundwater. However, it does not cause a significant risk of groundwater contamination. Our results of heavy metals do not agree with their results because mercury, lead and cadmium concentrations were found to be higher in our samples, particularly those, which were obtained in pre-monsoon period. However, the results of the current study accord with those of Kataria et al. (2011), who found elevated concentrations of zinc and lead in well water in both the pre-monsoon and postmonsoon seasons. In current study, the decrease in heavy metal concentrations in post-monsoon season could be due to flooded water of heavy rains in the year 2011.

\section{Conclusion}

The following are the main finding:

Lead, mercury and cadmium concentration was higher than WHO limits in the water of the study area, whereas all other parameters in most of the water samples are within permissible limits. Higher level must be rectified by the concerned authorities in order to protect human health.

Conflict of Interest. The authors declare no conflict of interest

\section{References}

Anwar, M.S., Lateef, S., Siddiqi, G.M. 2010. Bacteriological quality of drinking water in Lahore. Biomedica, 26: 66-69.

Agbalagba, O.E., Agbalagba, O.H., Ononugbo, C.P., Alao, A.A. 2011. Investigation into the physicochemical properties and hydrochemical processes 
of groundwater from commercial boreholes in Yenagoa, Bayelsa State, Nigeria. African Journal of Environmental Science and Technology, 5: 473481.

APHA, 2005. Standard Methods for the Examination of Water and Wastewater. American Public Health Association (APHA), Washington, DC, USA.

$\mathrm{UN}, 2010$. The human right to water and sanitation: resolution A. RES/64/292 UN General Assembly, (adopted by the General Assembly, 3 August 2010). http://www. refworld.org/ docid/4cc 926b02.html Accessed 16 March, 2015.

Ata, S., Wattoo, F.H., Qasim, I., Wattoo, M.H.S., Tirmizi, S.A., Qadir, M.A. 2013. Monitoring of anthropogenic influences on underground and surface water quality of Indus River at district Mianwali-Pakistan. Turkish Journal of Biochemistry, 38: 25-30.

Daud, M.K., Nafees, M., Ali, S., Rizwan, M., Bajwa, R.A., Shakoor, M.B., Arshad, M.U., Chatha, S.A.S., Deeba, F., Murad, W., Malook, I., Zhu, S. J. 2017. Drinking water quality status and contamination in Pakistan. BioMed Research International, DOI: 10.1155/2017 7908183 .

Dhonde, S.M., Kulkarni, G.B. 2012. Hydro-chemical monitoring of drinking water in Kadi River at Nimgaon Choba Project in Beed dist.(MS) India. Bioscience Discovery, 3: 133-137.

Farooq, M.A., Zubair, A., Shaukat, S.S., Zafar, M.U., Ahmad, W. 2013. Water quality characteristics of Keenjhar Lake, Sindh Pakistan. World Applied Sciences Journal, 27: 297-301.

Gillespie, S.H. 1994. Medical Microbiology Illustrated: 296 pp., $1^{\text {st }}$ edition, Butterworth-Heinemann. Elsevier, Science, the Netherlands.

Houdas, Y., Ring, E.F.J. 1982. Human Body Temperature: Its Measurement and Regulation. 238 pp. Springer Science \& Business Media, Germany.

Ihsanullah, K.M., Khattak, T.N., Sattar, A. 1991. Determination of different contaminants in selective drinking water samples collected from Peshawar valley area. Nucleus (Islamabad) 36: 91-97.

InamUllah, E., Alam, A. 2014. Assessment of drinking water quality in Peshawar, Pakistan. Bulgarian Journal of Agricultural Science, Agricultural Academy, 20: 595-600.

Kataria, H.C., Gupta, M., Kumar, M., Kushwaha, S., Kashyap, S., Trivedi, S., Bhadoriya, R., Bandewar, N. K. 2011. Study of physico-chemical parameters of drinking water of Bhopal city with reference to health impacts. Current World Environment, 6: 9599.

Khan, A.R., Akif, M., Wadud, S., Khan, K. 1999. Pollution studies of Kabul river and its tributes for the assessment of organic strength and fecal coliform. Journal of the Chemical Society of Pakistan, 21: 41-47.

Korai, A.L., Sahato, G.A., Lashari, K.H., Arbani, S.N. 2008. Biodiversity in relation to physicochemical properties of Keenjhar Lake, Thatta district, Sindh, Pakistan. Turkish Journal of Fisheries and Aquatic Sciences, 8: 259-268.

Lashari, K.H., Sahato, G.A., Korai, A.L., Naqvi, S.H., Palh, Z.A., Urooj, N. 2012. Heavy metals burden of Keenjhar Lake, District Thatta, Sindh, Pakistan. African Journal of Biotechnology, 11: 12305-12313.

Lashari, K.H., Korai, A.L., Sahato, G.A., Kazi, T.G. 2009. Limnological studies of Keenjhar lake, district, Thatta, Sindh, Pakistan. Pakistan Journal of Analytical and Environmental Chemistry, 10: 39-47.

LeChevallier, M.W., Norton, W.D., Lee, R.G. 1991. Giardia and Cryptosporidium spp. in filtered drinking water supplies. Applied and Environmental Microbiology, 57: 2617-2621.

Lee, S.H., Levy, D.A., Craun, G.F., Beach, M.J., Calderon, R.L. 2002. Surveillance for waterborne-disease outbreaks--United States, 1999-2000. Morbidity and Mortality Weekly Report. Surveillance summaries (Washington, DC: 2002), 51: 1-47.

Lester, J.N., Sterritt, R.M. 1988. Microbiology for Environmental and Public Health Engineers, 278 pp. CRC Press London, UK.

Oyinloye, A.O., Jegede, G.O. 2004. Geophysical survey, geochemical and microbiological investigation of ground and well water in Ado-Ekiti North-East, South-Western Nigeria. Global Journal of Geological Sciences, 2: 235-242.

Rahman, A., Chughtai, M.O. 2014. Reginol interpretation of river Indus water quality data using regression model. African Journal of Environmental Science and Technology, 8: 86-90.

Shar, A.H. 2010. Isolation and Identification of Pathogenic Bacteria from Drinking Water of Khairpur, Sukkur and Rohri. Ph.D. Thesis, 252 pp., Shah Abdul Latif University Khairpur, Pakistan.

Shar, A.H., Kazi, Y.F., Kanhar, N.A., Soomro, I.H., Zia, S.M., Ghumro, P.B. 2010. Drinking water quality in Rohri city, Sindh, Pakistan. African Journal of Biotechnology, 9: 7102-7107. 
Shar, A.H., Kazi, Y.F., Soomro, I.H., Zardari, M. 2009. Bacteriological quality of drinking water of Sukkur City. Pakistan Journal of Medical Research, 48: 88-90.

Swain, A. 2004. Managing Water Conflict: Asia, Africa and the Middle East. Routledge. 220 pp. London, UK.

Tahir, M.A., Rasheed, M.H., Imran, M.S. 2010. Water Quality Status in Rural Areas of Pakistan. pp 94. Pakistan Council of Research in Water Resources (PCRWR). Printing Corporation of Pakistan Press, Islamabad Pakistan.

Tiuri, M., Hallikainen, M. 1981. Microwave emission characteristics of snow covered earth surfaces measured by the Nimbus-7 satellite. $11^{\text {th }}$ European Microwave Conference, Amsterdam, Netherlands. pp. 233-238.

WHO, 2004. Guidelines for drinking-water quality. vol. 1, 540 pp., $3^{\text {rd }}$ edition, Geneva, Switzerland.

Zafar, M.U. 2013. Water Analysis and Climatic History of Gilgit And Hunza Valleys (A Dendroclimatic Approach. Ph. D. Thesis, 171 pp., Federal Urdu University of Arts, Science and Technology Gulshan-e-Iqbal Campus, Karachi, Pakistan.

Zubair, A., Hussain, A., Farooq, M.A., Abbasi, H.N. 2010. Impact of storm water on ground quality below retention/detention basins. Environmental Monitoring Assessment, 162: 427-437. 